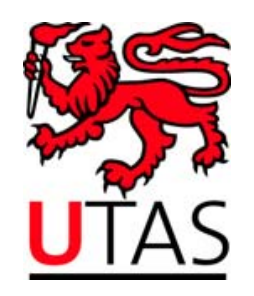

SCHOOL OF ECONOMICS AND FINANCE

Discussion Paper 2012-12

The Industrial Impact of Monetary Shocks during the Inflation Targeting Era in Australia

Joaquin L Vespignani

ISSN 1443-8593

ISBN 978-1-86295-687-2 


\title{
The industrial impact of monetary shocks during the inflation targeting era in Australia
}

\author{
Joaquin L. Vespignani
}

University of Tasmania, School of Economics and Finance

\begin{abstract}
In this article we analyse the industrial impact of monetary shocks since inflation targeting has been introduced in Australia (1990). These impacts are quantified by constructing a structural vector autoregressive (SVAR) model for a small open economy. Our results show that construction and manufacturing industries exhibit a significant reduction in gross value added (GVA) after an unanticipated rise in the official cash rate. However, the finance and insurance industry, and the mining industry, seem to be unaffected by these shocks.
\end{abstract}

JEL categories: E50, E58 and C32

Key words: Monetary shocks, Industrial response, Industrial composition and VAR model 


\section{Introduction}

The major objective of this article is to understand the transmission mechanism of monetary shocks in Australia since inflation targeting was introduced in early 90ô and to provide valuable information regarding which industries are more affected by this policy.

Consequently, in this article a structural vector autoregressive (SVAR) $\operatorname{model}^{1}$ is built to address the issue of the impact of monetary shocks at the industrial level using disaggregated gross value added (GVA) data for each industry classification. ${ }^{2}$ We focus most rigorously on the largest industries in the Australian economy, namely, finance and insurance services; manufacturing; construction; mining; professional, scientific and technical services; and health care and social services.

The Australian economy has a wide diversity of industries that contribute significantly to GDP; as a modern developed economy, Australia has increased the share of services and reduced the share of manufacturing in the economy. Table 1 shows evidence of this fact; while finance and insurance; professional, scientific and technical services; and health care and social assistance services have increased by around 68\%, 90\% and 35\% respectively between 1974 and 2009, the manufacturing industry has decreased around $48 \%$ as a percentage of GDP.

The change to industrial contribution in Australia constitutes an important factor in regard to monetary shocks. In particular, the impact of monetary shocks can change over time due to changes in the industrial composition of the economy. For example, if

\footnotetext{
${ }^{1}$ For more detail about SVAR, Enders, Applied Econometrics, p. 264.

${ }^{2}$ For more detail see ABS, Cat: 1292, p. 96, Australian and New Zealand Standard Industrial Classification (ANZSIC) 2006.
} 
an industry that is sensitive (nonsensitive) to interest rate variations increases (decreases) its share in the economy, monetary shocks will gain (lose) impact.

Figure 1 illustrates industrial share as a percentage of GDP, and it can be seen that the four largest industries in Australia constitute around 32\% of GDP. Those industries are finance and insurance (9.9\%), followed by manufacturing (8.4\%), construction $(7.0 \%)$ and mining (6.7\%). While this Australian Bureau of Statistics (ABS) classification is helpful in describing industries with similar characteristics, it may be useful to disaggregate them further (subject to data availability), as some industries aggregated in the same categories may have unique different responses to monetary shocks.

\section{Literature Review}

\section{Industrial impact of monetary policy (international literature review)}

One of the first papers to find that monetary shocks impact differently across industries was published using the United States (US) quarterly data from 1958 to $1992{ }^{3}$ The motivation of the authors was the fact that monetary policy theory describes monetary policy actions as having a ániform national effectô when in reality the nation is composed of very diverse regions which are likely to be affected differently by monetary policy actions ${ }^{4}$.

This article relates the differential statesô responses to an unanticipated increase in interest rate to differences in industrial composition across states. Their paper finds that:

\footnotetext{
${ }^{3}$ By Carlino and Defina, The differential regional effect, p. 572-87.

4 Carlino and Defina, The differential regional effect, p. 572.
} 
The size of a stateâs response to a monetary policy shock is positively related to its share of construction and durable goods manufacturing and negatively related to its share of extractive industries and finance, insurance and real estate industries. ${ }^{5}$

Ganley and Salmon (1997) studied the impact of monetary policy shocks on the output of 24 industries in the United Kingdom (UK) economy. The purpose of this research was to identify the speed and magnitude of the reactions of firms in different sectors to an unanticipated change in the cash rate shock. In addition, this research aims to provide stylised facts about sectorial responses to monetary policy shocks for the UK.

The main conclusions of the paper are: a) construction and manufacturing output declines sharply and rapidly in response to contractionary monetary policy, and b) the largest output reduction in response to monetary policy contractions is exhibited by small firms.

Hayo and Uhlenbrock (1999) studied the industrial effect of monetary policy in Germany with monthly data from January 1978 to December 1994, using a separate VAR model for each industry and only using endogenous variables. The main findings of their paper are that nonferrous metal, chemical, iron, steel, electrical engineering and office machinery manufacture industries show evidence of a significant negative production movement in response to an unanticipated increase in the interest rate. By contrast, clothing, food, mining, oil, printing, ship building, manufacture of tools and metal product industries respond positively to an unanticipated increase in interest rate.

Regarding the industrial effect of monetary policy in large developed economies, Dedola and Lippi (2005) developed a panel-VAR model to study the monetary transmission mechanism in five Organisation for Economic Co-operation and

\footnotetext{
${ }^{5}$ Carlino and Defina, Do states respond differently, p.24.
} 
Development (OECD) countries (France, Germany, Italy, UK and the US) at industry level with quarterly data from January 1975 to December 1997. The motivation of this study was to use the same model for different developed countries to uncover stylized facts for large economies regarding the different industrial impacts of monetary policy.

The model is constructed using the following endogenous variables: the industrial production, the consumer price index, the commodity price index, the short-term rate, the M3 or M1, and the exchange rate. From this study, the following conclusion emerges: the impact of an unanticipated increase in interest rate is stronger in industries that produce durable goods, have a greater financial requirement to produce, and have a small borrowing capacity.

A shortcoming of many previous studies is that in most cases the effect of the world economy is under-represented or not specified at all. In particular, neither the Ganley and Salmon (1997) nor Dedola and Lippi (2005) models account for any exogenous variables to control for world economy shocks. Furthermore, the Dedola and Lippi (2005) model uses commodity price index as an endogenous variable. While this assumption may be reasonable for a large economy able to influence commodity prices, such as the US or Germany, it may not be appropriate for the other, smaller economies studied, such as France, Italy and the UK.

\section{Australian macroeconomic models}

The SVAR model developed by Dungey and Pagan (2000) was one of the first models of the Australian economy to include the small open economy assumptions incorporating international variables. The purpose of this paper was to construct a quantitative macroeconomic model for the aggregated Australian economy.. While the 
effect of monetary policy on an aggregated economy is also estimated, this paper has a very broad drive, including both the estimation of most domestic and international macroeconomic shocks to Australian output, inflation, exchange rate and other macroeconomic variables.

The authors employ an 11-variable SVAR model using Australian data from the first quarter of 1980 to the third quarter of 1998. The model also imposes different restrictions, the most innovative being to not allow feedback from the domestic variable to all foreign variables, since Australia is a small open economy.

Similarly, to Dungey and Pagan (2000), Brischetto and Voss (1999) also constructed an SVAR model for the Australian economy. Nevertheless, the purpose of this paper is narrower, as the impact of monetary policy is the only focus. Having only this purpose in mind, the authors developed a 7-variable SVAR model for the Australian economy based on the model of Kim and Roubini (1999). Imposing only five restrictions, the model is largely recursive except in the relationship between the domestic interest rate, the monetary aggregate and the nominal exchange rate.

Berkelmans (2005) constructed a 7-variable SVAR model for the Australian economy with the narrower objective of examining the relationship of credit with other macroeconomic variables. This paper applies significantly fewer contemporaneous restrictions than Brischetto and Voss (1999); however, it imposes restrictions on the lag structure. The main innovation of this model is the inclusion of a credit variable rather than a monetary aggregate since the intention is to capture credit shocks.

The more relevant findings of this study are that in the short term, shocks to the interest rate, the exchange rate and past shocks to credit are important to explain changes in 
contemporaneous credit. Nevertheless, over the longer term, shocks to output, inflation and commodity prices have a greater influence on credit.

Most recently, Dungey and Pagan (2009), extended their 2000 model to include the nonstationarity and co-integrating properties of the data. The main objectives of this study were to introduce the linkages between new Keynesian and dynamic stochastic general equilibrium theoretical models, and the empirical evidence arising from the SVAR model.

The main extensions from the 2000 model are to treat the real US GDP, the real Australian exports, the real Australian Gross National Expenditure (GNE), the real Australian GDP, and the real trade-weighted index of the Australian dollar as integrated variables of order one I (1). The quarterly inflation rate, the ratio of the Dow Jones index to the US Consumer Price Index (CPI), the ratio of the All Ordinaries index to the Australian implicit price deflator, the US 90-day interest rate and the Australian cash rate are treated as integrated variables of order zero I (0).

The major findings of this paper are that Australian data does not support the new Keynesian models, because the SVAR model constructed supports the presence of some structures which are not present in the new Keynesian model. Comparing the Dungey and Pagan 2000 version to the 2009 version, the latter study suggests that the 2000 version overstated the impact of monetary policy on macroeconomic activity. 


\section{Causes of the Differential Effect of Monetary Shocks across Industries}

Among the main causes of the differential effect of monetary shocks across industries, the literature highlights differences in firm size, the production of durable and nondurable goods, the export/import share of total output, and the proportion of debt.

\section{Differences in firm size across industries}

This premise is based on the findings of Gertler and Hubbard:

There is a strong correlation between size and the form of external finance. Smaller firms rely heavily on intermediary credit while large firms make far greater use of direct credit, including equity, public debt, and commercial paper.(Gertler and Hubbard, 1994, p.313).

In short, small firms have small borrowing capacity and depend solely on domestic lenders, which reduces the supply of loans as the monetary policy contracts, whereas large firms have access to external or nonbank sources of financing.

Figure 2 shows that mining; electricity, gas, water and waste services; and information media and telecommunications are highly concentrated industries, since more than $70 \%$ of the respective GVA is produced by large firms. In addition, the financial industry (not reported by ABS data) is perhaps the most concentrated industry in Australia, given that the four largest banks dominate $31 \%$ of the financial industry market share and $84 \%$ of the lending market share. ${ }^{6}$ Meanwhile, construction, and rental, hiring and real estate services have a very large share of the GVA produced by small firms, while the remaining industries present a more balanced share of the GVA produced by firm size.

${ }^{6}$ Source: IBISWorld, Finance in Australia, code: K7300. 


\section{Differences in production of durable versus nondurable goods across industries}

A common finding in the study of the differential impact of monetary shocks across industries is that the durable goods producers are more severely affected by monetary contractions than the nondurable goods producers. For example, Erceg and Levin (2002) have found that the impact of monetary contractions on durable goods is up to five times higher than on nondurable goods. Dedola and Lippi (2005) also studied this issue, finding that durable goods fluctuate more than nondurable goods with changes in the interest rate.

The logic behind this different response is that the purchases of durable goods are financed by loans which are scarcer when monetary policy contracts, while nondurable goods are generally not financed by loans.

\section{Differences in export/import proportion across industries}

Following the Mundell and Fleming (MF) model, the effect of monetary shocks on the international trade balance can be summarised as follows:

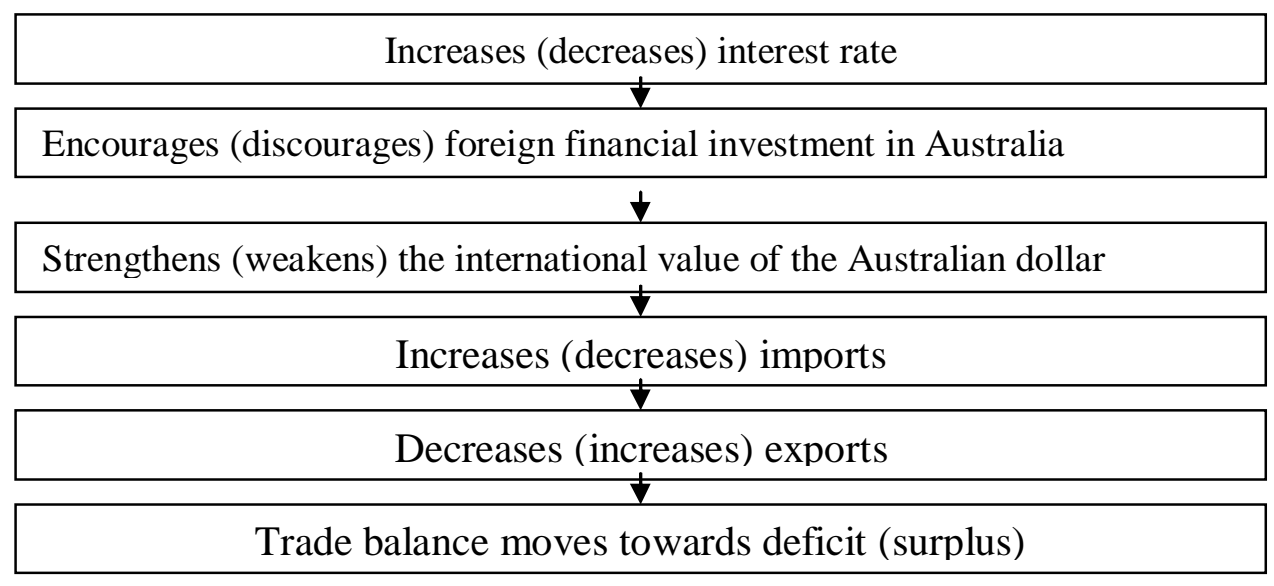

While the MF model explores this effect at the macro level, it seems reasonable to consider that the effect of monetary shocks on the trade balance would have a different 
effect across industries which have a disparate export and/or import proportion of total outputs. To analyse this matter, Figure 3 explores the exports/imports proportion of the largest contributors to Australian international trade in 2008. This figure shows that mining exports in 2008 represented more than $50 \%$ of Australian exports. Metal products; and food, beverage and tobacco products are the second and third largest exporters, representing some $16 \%$ and $9 \%$ of total exports respectively.

In respect of imports, the machinery and equipment industry is the largest importer, accounting for more than $40 \%$ of total imports. This is because mining producers need to import heavy equipment to operate successfully. Petroleum, coal, chemical and other rubber products; metal products; and textile, clothing and other manufacturing represent around $20 \%, 11 \%$ and $5 \%$ of total exports respectively.

The logic behind the MF theory is that exporters (importers) will be negatively (positively) affected by an unanticipated monetary contraction (expansion), but at the industrial level this issue seems to be more complicated, since it also depends on supply and demand elasticities. For example, consider the case of the mining industry in Australia: while a contractionary monetary policy would appreciate the Australian dollar (making Australian mining exports more expensive for the rest of the world), demand would not be affected (revenue alone would be reduced) since output is sold under long term contract. ${ }^{7}$ Meanwhile, this industry could still enjoy the benefit of importing cheaper equipment to expand production, given the stronger Australian dollar. In short, for some industries the monetary shocks that impact the industryinternational trade balance can be either neutral or reverse, depending on both demand and supply elasticities.

\footnotetext{
${ }^{7}$ For more information regarding long term contracts in the mining industry, see IBISWorld Industry Report, Mining Australia Report B, p. 18.
} 


\section{Differences in debt proportions across industries}

In this section we investigate the Australian industrial debt of domestic institutions as percentage of GVA.

Figure 4 shows the outstanding debts by industry in the period 2008. Note that data is only available for some industries. In 2008, finance and insurance; and wholesale and retail trade have the largest proportional debts with domestic financial institutions ( $107 \%$ and $85 \%$ respectively). On the other hand, the mining industry has a very low debt/GVA ratio for the whole period, this being $16 \%$ in 2008.

\section{Model Specification}

\section{Baseline model}

We constructed a SVAR model using Australian quarterly data from September $1990^{8}$ to December 2009 to analyse the impact of contractionary monetary shocks on industrial outputs. Our baseline model is Dedola and Lippi (2005). Several modifications have been made to account for the fact that Australia is a small, open economy and to address certain shortcomings of this model as discussed in Section 2.

The first major modification is to use commodity prices as exogenous variables rather than endogenous variables as part of the small open economy assumptions (the Australian economy is too small to impact world commodity prices).

Secondly, instead of using total industrial production as a proxy for the full economy, we believe it is more appropriate to use real GDP minus the industry in question. This modification reflects that the Reserve Bank of Australia (RBA) reaction function

\footnotetext{
${ }^{8}$ First period of inflation targeting (official cash rate) reported by the RBA.
} 
depends on domestic inflation and the full domestic economy (rather than a particular sector). More specifically, we included the variable $A G D P_{-i, t}$ which is simply the real GDP gross rate minus the real GVA gross rate of the industry $(i)$.

Thirdly, in the model we decided to include the endogenous variable, aggregated credit $\left(C R E D_{t}\right)$, which accounts directly for all credits in the financial system, rather than the measure of a money supply M1. This modification allows us to control for more factors that may reduce the impact of contractionary monetary policy; for example, international funds obtained by domestic financial institutions and/or a willingness to lend to consumers in the domestic market.

Finally, the most important adjustment to this model of the Australian economy is the introduction of small open economy assumptions, following Dungey and Pagan (2000). The principal idea is to not allow feedback from domestic to international variables, because Australia is a small open economy incapable of influencing international variables.

\section{Variable selection}

We selected the following endogenous variables. $A G D P_{-i, t}$ which is simply the real GDP minus the real GVA of the industry $(i)$. The industrial GVA $\left(I N D_{i t}\right)$, which is the only measurement of industrial output reported quarterly by the ABS. The Australian consumer price $\left(A C P I_{t}\right)$, for which, more specifically, we decided to use the weighted median (measure of underlying inflation), because this indicator significantly reduces the seasonality effect. ${ }^{9}$ The official cash rate $\mathrm{CASH}_{t}$ the only measure of

\footnotetext{
${ }^{9}$ Note that ABS does not produce a seasonally adjusted CPI.
} 
inflation targeting; the total domestic credits $\left(C R E D_{t}\right)$, and the trade weighted index of the Australian dollar $\left(A T W I_{t}\right) .^{10}$

Finally, in line with most international studies, ${ }^{11}$ we estimated our SVAR model one industry at a time and then compared the results. Although a model containing all industries would be ideal, this cannot be done with scarce macro-data using a VAR model.

The SVAR can be expressed in matrix form (for simplicity the constant term is omitted):

$$
B_{0} X_{t}=B_{1} X_{t-j}+\text { exogenous_vectors }+\varepsilon_{t}
$$

Where $j=1,2,3$ and $X_{t}$ is vector of endogenous variables:

$$
X_{t}=\left[A G D P_{-i, t}, I N D_{i t}, A C P I P C_{,}, C A S H_{t}, C R E D I T, A T W I_{t}\right](2)
$$

By introducing the following exogenous vectors ${ }^{12}$, the small open economy assumption is materialized; the terms of $\operatorname{trade}\left(T O T_{t}\right)$, the US GDP $\left(U S G D P_{t}\right)$, the US inflation $\left(U S C P I_{t}\right)$, the US interest rate $\left(U S I R_{t}\right)$ and the Australian commodity price index $\left(\mathrm{COM}_{t}\right)$. The US variables $U S G D P_{t}, U S C P I_{t}, U S I R_{t}$ are used as proxies for the world GDP, the world inflation rate and the world interest rate respectively, and are able to affect a small open economy throughout trade and investment flows. The purpose of the variable $T O T_{t}$, is to control for any change in trade conditions for the Australian economy resulting from external factors; for example, an increase in the demand for

\footnotetext{
${ }^{10}$ Descriptions and sources of all variables can be found in Appendix I.

${ }^{11}$ E.g. Dedola and Lippi, The monetary transmission mechanism, pp. 1543-69 and Georgopoulos, Measuring regional effects, pp. 2093-113.

12 Note that the exogenous variables are exogenous with respect to domestic variables but also exogenous amongst themselves.
} 
Australian goods by any trade partner. Finally, the inclusion of $C O M_{t}$ in the model accounts for the fact that the Australian economy is quite dependent on commodity prices, which are determined on the international market.

\section{Identification}

In line with most VAR studies, restrictions are only imposed on the contemporaneous structure.. Our benchmark identification matrix is based on Dedola and Lippi (2005), but incorporating some characteristics of Australia data. In our model the $\Delta \log \left(A G D P_{-i, t}\right)$ is only affected contemporaneously by the $\Delta \log \left(A T W I_{t}\right)$, assuming that production decisions are made before all information but the exchange rate for the contemporaneous quarter is realized. The $\Delta \log \left(I N D_{i t}\right)$ is affected only contemporaneously by the rest of the economy, as well as $\Delta \log \left(A T W I_{t}\right)$, since the rest of the economy is always much larger than any particular industry and therefore capable of contemporaneously affecting each individual industry.

$A C P I P C_{t}$ is only affected contemporaneously by $\Delta \log \left(A G D P_{-i, t}\right), \quad \Delta \log \left(I N D_{i t}\right)$ and $\Delta \log \left(A T W I_{t}\right)$, assuming that the level of production can impact inflation in the same quarter throughout consumer demand.

Although in Dedola and Lippi (2005), the $\mathrm{CASH}_{t}$ equation is affected contemporaneously to both output and inflation, In our study the $\mathrm{CASH}_{t}$ equation is only affected contemporaneously by $\Delta \log \left(A T W I_{t}\right)$ since only the international outputs can be seen in the same quarter in Australia by the RBA. This is because $\Delta \log \left(A G D P_{t}\right)$ and $A C P I P C_{t}$ data are released in Australia, more than two months after monetary decisions are made. In similar fashion $\Delta \log \left(C R E D_{t}\right)$ is affected 
contemporaneously by $\Delta \log \left(A T W I_{t}\right)$, but also by $C A S H_{t}$, assuming that lenders take action as quickly as the RBA makes monetary policy decisions.

In line with most domestic studies such as. Dungey and Pagan 2000 and 2009, and Brischetto and Voss (1999). The $\Delta \log \left(A T W I_{t}\right)$ equation is affected contemporaneously by all variables. This is because exchange market operators can observe and arbitrage quickly on the release of any indicator from either the Australian or the international economy. Finally, we assume that all exogenous variables affect all equations only contemporaneously, since domestic economic agents can look at movements in international outputs, commodity prices and the exchange rate in the same quarter.

$$
B_{0} X_{t}=\left[\begin{array}{cccccc}
1 & 0 & 0 & 0 & 0 & -b_{16} \\
-b_{21} & 1 & 0 & 0 & 0 & -b_{26} \\
-b_{31} & -b_{32} & 1 & 0 & 0 & -b_{36} \\
0 & 0 & 0 & 1 & 0 & -b_{46} \\
0 & 0 & 0 & -b_{54} & 1 & -b_{56} \\
-b_{61} & -b_{62} & -b_{63} & -b_{64} & -b_{65} & 1
\end{array}\right]\left[\begin{array}{c}
\Delta \log \left(A G D P_{-i, t}\right) \\
\Delta \log \left(I N D_{i t}\right) \\
A C P I P C_{t} \\
C A S H_{t} \\
\Delta \log \left(C R E D_{t}\right) \\
\Delta \log \left(A T W I_{t}\right)
\end{array}\right] \text { (3) }
$$

Given these restrictions, the model is over-identified because there is one more zero parameter restriction than necessary to identify the model exactly. Consequently, the likelihood ratio test for over-identification is performed. In all models, the null hypothesis that restrictions are valid cannot be rejected at conventional levels, indicating that restrictions are reasonable.

\section{Functional Form Strategy}

To select the lag length, the Akaike Information Criterion (AIC) and the Schwarz Criterion (SC) are estimated for the largest industries. While the AIC selected four lags in most cases, the SC selected only one. In applied studies, it is common to use the 
average lags between those criteria when no particular theory or intuition supports any particular lag length. Consequently, and in line with most Australian studies (e.g Dungey and Pagan 2009), we selected three lags, providing better trade-off between omitted variables and the reduction of degree of freedom.

In line with most studies, our strategy is to use all variables but interest rates in logarithm form. We use variables in levels if a variable is stationary and in first difference if a variable is nonstationary in levels but first-difference stationary in order to avoid spurious regression. Consequently, the Augmented Dickey Fuller test (ADF) is performed. The null hypothesis of unit root can be easily rejected at the $5 \%$ level for both the $A C P I P C_{t}{ }^{13}$ and the $C A S H_{t}$. However, the $\log \left(C R E D_{t}\right), \log \left(A G D P_{t}\right)$ and $\log \left(A T W I_{t}\right)$ are only first-difference stationary, as the ADF test cannot reject the null hypothesis of unit root in level but can easily reject the null hypothesis in first difference at $5 \%$ level.

Regarding the industrial variables, the ADF test shows that most industriesôreal GVA are only first-difference stationary (only four out of 27 industries are level stationary). ${ }^{14}$ While those four industries could be estimated in log-level without risk of spurious regression, our decision is to use all industriesôreal GVA variables in first difference to permit a fair comparison among industries. Finally, the exogenous variables are tested, finding that the $\log \left(U S G D P_{t}\right), \log \left(U S C P I_{t}\right)$ and $\log \left(T O T_{t}\right)$ are only first-difference stationary, while the $U S I R_{t}$ and $\log \left(C O M_{t}\right)$ are level stationary. ${ }^{15}$

\footnotetext{
${ }^{13}$ Note that the CPI weighted median used is already reported by RBA in percentage change.

${ }^{14}$ Those industries are: nonmetallic mineral products; machinery and equipment; information and telecommunication; and public administration services.

${ }^{15}$ For robustness of this analysis both, the Phillips-Person and the Kwiatkowski-Phillips-Schmidt-Shin unit root tests are also estimated, confirming the ADF results.
} 
We explore the possibility of some co-integration relationship among nonstationary variables in our model, as some important information can be lost when first difference transformation is used in nonstationary variables (see for example Enders (2004), page 328). Based on macroeconomic theory, and studies such as Dungey and Pagan (2009) the most likely nonstationary and co-integrated relationships to study in our models are the relationship among technologies: that is, those among $I N D_{i t}, G D P_{t}$ and $U S G D P_{t}$. We studied this issue using the Johansen co-integration test ${ }^{16}$ to find that this relationship holds only for some industries, which makes it difficult to compare results across industrial models in our study. Another possible co-integration relationship is among $C O M_{t}, T O T_{t}$ and $A T W I_{t}$ as commodity prices drive the term of trade and the real exchange rate. However, in our sample period $C O M_{t}$ seems to be consistently level stationary and the Johansen co-integration test for this period does not support the argument for a co-integration vector among these variables. Consequently, we decided to follow Dedola and Lippi (2005) and used the first difference of variables which are only first difference stationary.

\section{Results of SVAR (Largest Industries)}

Figure 5 shows the dynamic response to an unanticipated positive change in the cash rate shock ${ }^{17}$ or Impulse Response Function (IRF) ${ }^{18}$ for the six largest industries in Australia. In the first set of charts, the industry output responses to those shocks are shown. In the second set of charts and to conserve space, only the responses of

\footnotetext{
${ }^{16}$ For details of this test please see Enders, Applied Econometrics, p. 362.

${ }^{17}$ For each impulse response figure, the horizontal axis shows the number of periods. Each period represents a quarter. The vertical axis is expressed in percentage change. The dash lines represent a one standard deviation band around the estimates of the coefficients of the IRF. The confidence bands are obtained using Monte Carlo integration as described by Sims, Macroeconomics and Reality, pp. 1-48, where 500 draws were used from the asymptotic distribution of the VAR coefficient.

${ }^{18}$ For more detail about IRF, see Enders, Applied Econometrics, p. 272.
} 
underlying inflation, real credit, real Trade Weighted Index (TWI) and real GDP less the GVA for the largest industry in Australia (finance and insurance) are shown. Nevertheless those responses are very similar for all industrial models.

\section{Response of industrial GVA}

In Figure 5(a), the industrial response to an unanticipated rise of 100 basis points in the official cash rate is observed. The construction; manufacturing; and professional, scientific and support services suffer a large reduction in the real GVA gross rate of up to around $2.8 \%, 2.2 \%$ and $1.8 \%$ respectively. For the first two industries, the large negative impact is consistent with previous international findings. ${ }^{19}$ These responses can be substantiated by the fact that both industries produce mostly durable goods, have a large proportion of small and medium firms, and have relatively large debts with domestic financial institutions. In the case of the manufacturing industry, the effect is extended by the exchange rate appreciation, since manufacturing products can be substituted by cheaper imports.

Regarding the professional, scientific and support services, no previous studies have been found for comparison. This industry has a large proportion of small firms but produces nondurable goods and has a relatively small exposure to international trade. Given this mixed direction, no particular intuition can be applied.

The finance and insurance, and mining industries both seem to quickly revert the negative impact to reach a maximum of around $1.2 \%$ and $1.1 \%$ respectively. These findings are consistent with international findings. ${ }^{20}$ The finance and insurance positive

\footnotetext{
19 See for example Carlino and Defina, Do States Respond differently, pp. 17-27.

${ }^{20}$ For the mining industry Hayo and Birgit, Industry Effects, reported a positive effect on the mining industry and Georgopoulos, Measuring regional effects, pp. 2093-113, reported a positive effect on the financial and insurance industry.
} 
response is connected with the fact that this industry is dominated by very large banks with access to international financing.

The marginally positive response of the mining industry is associated with the characteristics of this industry, in which the market is dominated by very large firms with low debts to domestic institutions and access to external or nonbanking sources of financing. On the other hand, a large proportion of this output is exported; however, those exports are traded with long term sales contracts which may offset the impact of exchange rate appreciations on total demand.

Finally, for the health care and social services industry, the reduction in the real GVA gross rate is just below $1.3 \%$ in response to the shocks. This relatively small effect could be attributable to the extensive participation of the government in this industry, which may not be affected by interest rate variations.

\section{Response of inflation}

The CPI response to an unanticipated 100 basis points rise in the official cash rate is shown for only for the largest industry (finance and insurance). These figures show an incipient decrease in inflation (as expected) which then rises above the base line. This unclear response is a common finding in VAR studies and is attributed to the supply side effect of monetary policy ${ }^{21}$ as argued by Barth and Ramey:

Prices should rise (or not decrease) in the short-run following an unanticipated monetary contraction if the cost effects of the monetary transmission mechanism dominate the demand effects (Barth and Ramey, 2001, p.12).

${ }^{21}$ This issue was also studied by Bath and Ramey, The Cost Channel. 


\section{Response of real credit}

The responses of the real credit are shown; as expected, an unanticipated 100 basis points rise in the official cash rate unambiguously decreases the supply of credit in the domestic economy. This finding is consistent with the so-called áredit viewô based on the Bernanke and Blinder findings:

Tighter monetary policy results in a short-run sell-off of banks' security holdings, with little effect on loans. Over time, however, the brunt of tight money is felt on loans, as banks terminate old loans and refuse to make new ones. To the extent that some borrowers are dependent on bank loans for credit, this reduced supply of loans can depress the economy (Bernanke and Blinder, 1992, p.920).

\section{Response of real trade weighted index of australian dollar}

The response of the real TWI of the Australian dollar is plotted, and the results are consistent with the Mundell and Fleming theory, which states that a decrease in money supply appreciates the domestic interest rate relative to the global interest rate, attracting capital inflows and leading to an appreciation of domestic currency. More specifically, our model shows that an unanticipated 100 basis points rise in the official cash rate leads to an approximately $8 \%$ increase in the growth rate of the Australian dollar index.

\section{Response of real GDP}

In Figure 5(b), contractionary change in the cash rate unambiguously reduces real GDP. This is because higher interest rates reduce the amount of credit supplied by financial institutions and therefore consumption, but also make savings rather more attractive than consumption since banks also pay higher interest rates to depositors. 


\section{Cumulative impulse response}

The total impact of an unanticipated monetary shock can be evaluated using the Cumulative Impulse Response Function (CIRF) as shown in Figure 6. The CIRF confirms previous findings, such as the fact that the manufacturing and the construction industries are the most severely affected by these shocks (for both, around $4 \%$ decrease in real GVA growth rate is observed after 1 year), followed by professional, scientific and technical services; and the health care and social services industries (for both, up to a $2 \%$ decrease in growth rate is observed after the third quarter). By contrast, the mining industry and the finance and insurance industry quickly reversed an initial decrease in real GVA. After three quarters, both industries show an increase in real GVA gross rate (up to $1.0 \%$ for finance and insurance and $1.1 \%$ for mining).

\section{Results of SVAR Model (all industries) $)^{22}$}

In Table 2, the results for all industries are shown. In this table, the maximum/minimum responses and the periods in which they occur are reported. The results are ordered by the industries that are negatively affected, positively affected, or unaffected by the shocks

The machinery and equipment; petroleum, coal, chemical and rubber products and construction industries seem to have an unambiguously large cumulative drop in real GVA in response to the shocks (around 7\%, 5.3\% and 4.9\% decrease in real GVA gross rate, respectively).

\footnotetext{
${ }^{22}$ Note that the agricultural, fishing and forestry industry has been excluded from our analysis because some factors that affect the industry, such as droughts, temperature, etc., need to be considered when the response to monetary shocks in this industry is modelled, making comparison with other industries unreliable.
} 
For the first and last categories, the large impact may be attributable to the production of durable goods; however, for the petroleum, coal, chemical and rubber products industry, the higher level of data aggregation does not permit further analysis.

The rental, hiring and real estate services industry, by contrast, seems to be positively affected by the shocks. This result can be substantiated, since those services could substitute the consumption of durables such as housing, cars, hardware, etc., when contractionary monetary policy is implemented.

\section{Policy Implications}

Economic theory predicts that an increase in demand for particular goods raises the price and encourages firms to switch additional resources into the production of those goods. Consequently, the direct implication of our results is that contractionary monetary policy arising from the mining boom tends to accelerate the natural reallocation of resources when Australian relative prices of mining commodities increase.

The latest mining boom in Australia, which started in 2010, has generated the following dilemma for policymakers: while the mining boom creates upward pressures in the economy, lifting economic growth and inflation, it forces the RBA to contract monetary policy to keep inflation on target. These contractions have a greater effect on manufacturing and construction than on the mining sector implying that this policy accelerates the natural process of resources reallocation from the non-mining sector to the mining sector. 


\section{Conclusions}

In this article, we estimated the industrial impact of monetary shocks in Australia. We found that monetary shocks reduce the cumulative real GVA gross rate more severely in the construction and manufacturing industries. The reasons for this outcome are that in both industries, a very large proportion of the real GVA is produced by small or medium firms and there is a high dependency on domestic financing and the production of durable goods. In addition, the impact of these shocks on disaggregated sectors of the manufacturing industry was estimated. We found that the largest cumulative reduction in the real GVA gross rate within this industry is observed in the machinery and equipment industry, as well as the textile, clothing and other manufacturing sectors.

The mining industry seems to be unaffected or positively affected by monetary shocks, which is most likely due to a high proportion of real GVA produced by large firms and a very low dependency on domestic financing, together with inelastic demand.

Our results also show that the finance and insurance industry is unaffected or positively affected by these shocks. This finding is consistent with the ćost channelô view of monetary policy but also with the common belief that lenders benefit by contractionary monetary policy. This is because lenders may pass on the entire cost of borrowing domestically to customers; however, part of the actual cost is offset by borrowing more cheaply from international markets (until the domestic exchange rate appreciation restores the equilibrium). As a consequence, if the demand for loans is sufficiently inelastic, the increase in revenue could exceed the increase in cost for this industry, leading to an increase in the real GVA for this industry. ${ }^{23}$

${ }^{23}$ This is because GVA is constructed as revenue less cost. 
This finding has important implications in terms of Australian monetary policy. While a contractionary monetary policy attempts (in part) to reduce lending supply, this effort may be weakened in the presence of a highly concentrated financial industry with access to international funds, combined with an inelastic demand for loans.

Our findings further suggest that monetary policy could have become less powerful in shaping aggregate demand and inflation over the last four decades. This is because large industries that are positively impacted, or not impacted, by monetary shocks (e.g., the finance and insurance and mining industries) have substantially increased their share in the Australian economy. Meanwhile, the manufacturing industry, one of the most negatively impacted industries, has reduced its share in the economy. ${ }^{24}$

${ }^{24}$ These statistics were reported in Section 2 Table 2. 


\section{Appendix I Variable Descriptions}

Table 3 Variable descriptions (SVAR model 1).

The quarterly data used in the SVAR model is from September 1990 (first period of inflation targeting reported by the RBA) to the December 2009.

\begin{tabular}{|c|c|c|}
\hline Variable & Description & Source \\
\hline$I N D_{i t}$ & $\begin{array}{l}\text { Real GVA of Industry i } \\
\text { (seasonally adjusted). }\end{array}$ & $\begin{array}{l}\text { ABS, 5206.0 - Australian National } \\
\text { Accounts: National Income, Expenditure } \\
\text { and Product. GVA by Industry, Chain } \\
\text { Volume Measures, Table } 6 .\end{array}$ \\
\hline$A C P I P C_{t}$ & $\begin{array}{l}\text { Australian Prices, \% change } \\
\text { (Weighted Median). }\end{array}$ & RBA Statistics, Table G01. \\
\hline $\mathrm{CASH}_{t}$ & Official Cash Rate. & $\begin{array}{l}\text { RBA Statistics, Reserve Bank of Australia, } \\
\text { Monetary Policy Changes, Table A02. }\end{array}$ \\
\hline$C R E D_{t}$ & $\begin{array}{l}\text { Real Aggregated Credits } \\
\text { (including securitisation). }\end{array}$ & $\begin{array}{l}\text { RBA Statistics, Money and Credit } \\
\text { Statistics, Table D2, Lending and Credit } \\
\text { Aggregates. }\end{array}$ \\
\hline$A T W I_{t}$ & $\begin{array}{l}\text { Real Trade-Weighted Index of } \\
\text { Australian Dollar. }\end{array}$ & $\begin{array}{l}\text { RBA Statistics, Exchange Rates, Real } \\
\text { Exchange Rate Measures, Table F15. }\end{array}$ \\
\hline$T O T_{t}$ & Australian Term of Trade. & $\begin{array}{l}\text { ABS, } 5206.0 \text { - Australian National } \\
\text { Accounts, Series; A2304200A. }\end{array}$ \\
\hline$A G D P_{t}$ & Australian real GDP & $\begin{array}{l}\text { ABS, } 5206.0 \text { - Australian National } \\
\text { Accounts, Series. }\end{array}$ \\
\hline$U S G D P_{t}$ & $\begin{array}{l}\text { US Real Gross Domestic } \\
\text { Product (seasonally adjusted). }\end{array}$ & $\begin{array}{l}\text { International Financial Statistics (IFS), } \\
\text { International Monetary fund (IMF). US } \\
\text { GDP Seasonally Adjusted Code: } \\
\text { 99BIRZF. }\end{array}$ \\
\hline$U S C P I_{t}$ & $\begin{array}{l}\text { US Consumer Price Index } \\
\text { (seasonally adjusted). }\end{array}$ & $\begin{array}{l}\text { IFS, IMF Consumer Price Index, series: } \\
11164 Z F \text {. }\end{array}$ \\
\hline$U S I R_{t}$ & US Interest Rate. & $\begin{array}{l}\text { IFS, IMF, Money Market, US Interest Rate } \\
\text { Quarterly. Code. 60CZF. }\end{array}$ \\
\hline $\mathrm{COM}_{t}$ & $\begin{array}{l}\text { Australian Commodity Prices } \\
\text { Index (seasonally adjusted). }\end{array}$ & $\begin{array}{l}\text { RBA Statistics, Prices and Inflation, Table } \\
\text { G05, RBA Index of Commodity Prices. }\end{array}$ \\
\hline$\Delta$ & First Difference Operator. & \\
\hline Log & Natural Logarithm. & \\
\hline
\end{tabular}




\section{Appendix II Sensitivity Analysis}

\section{Autocorrelation and Heteroskedasticity Tests}

To test for autocorrelation, the residual serial correlation LM test is used, because the data utilised in this study is quarterly, we decided to use eight lags (two years) in this test, in case some seasonality effect is present. The results for the 27 models are estimated. For most of the models (20 out of 27), the null hypothesis of no serial correlation cannot be rejected in the first lag (at the 5\% level). Additionally, for all seven models that exhibit some correlation in the first lag, the autocorrelation completely disappears at the third lag. The results are also confirmed by the VAR residual cross-correlation (correlograms).

Concerning heteroskedasticity, the residual heteroskedasticity LM tests for all models is estimated. For all models, the null hypothesis of no heteroskedasticity of the joint combinations of all error term products cannot be rejected at the 5\% level. As a result of the tests performed in all models, the hypothesis of both the presence of autocorrelation and heteroskedasticity are discarded.

\section{Stability Condition}

An important condition to be satisfied in any VAR model is that the lag structure included also has to be stationary. The inverse roots of AR characteristic polynomial are plotted. ${ }^{27}$ For our 27 estimated models, these tests show that no root lies outside the unit circle, suggesting that our models have stable roots.

\footnotetext{
${ }^{27}$ For more detail regarding this test, see Enders, Applied Econometrics, p. 266.
} 


\section{Reference List}

Barth, M.J. and Ramey, V.A. (2001), The cost channel of monetary transmission, NBER Working Paper No.7675.

Berkelmans, L. (2005), Credit and monetary policy: an Australian SVAR, Reserve Bank of Australia Discussion Paper No. 2005-6.

Bernanke ,B.S. and Blinder, A.S. (1988), Credit, money, and aggregate demand The American Economic Review, Papers and Proceedings of the One-Hundredth Annual Meeting of the American Economic Association, 78: 435-439.

Bernanke, B.S. and Blinder, A.S. (1992), The federal funds rate and the channels of monetary transmission American Economic Review, 82: 901-21.

Brischetto, A. and Voss, G. (1999), A structural vector autoregressive model of monetary policy in Australia, Reserve Bank of Australia Research Discussion Paper 1999-11.

Carlino, G. and DeFina, R. (1998), The differential regional effect of monetary policy, The Review of Economics and Statistics, 4: 572-87.

Carlino, G.A. and DeFina, R. (1999), đo states respond differently to changes in monetary policy?Q̂ Business Review, July: 17-27.

Dedola, L. and Lippi, F. (2005), The monetary transmission mechanism: evidence from the industries of five OECD countries, European Economic Review, 49: 1543-1569.

Dungey, M. and Pagan, A. (2000), A structural VAR model of the Australian economy, The Economic Record, 76: 321-342.

Dungey, M. and Pagan, A. (2009), Extending a SVAR model of the Australian economy, The Economic Record, 85: 1-20.

Enders, W. (2004), Applied Econometric Time Series, 2nd edn, John Wiley and Sons, New York.

Erceg, C.J. and Levin, A.T. 2002, Optimal monetary policy with durable and nondurable goods International Finance Discussion Papers No.74.

Ganley, J. and Salmon, C. (1997), The industrial impact of monetary policy shocks: some stylized fact, Bank of England, Working Paper No. 68.

Georgopoulos, G. (2009), Measuring regional effects of monetary policy in Canada, Applied Economics, 41:16, 2093-2113.

Gertler, M. and Hubbard, R.G. (1988), Financial factors in business fluctuations, NBER, Working Paper No. 2758.

Hayo, B. and Uhlenbrock, B. (1999), Industry effects of monetary policy in Germany Center for European Integration Studies, Working Paper; B13-1999. 
Kim, S. and Roubini, N. (1999), Exchange rate anomalies in the industrial countries: A solution with structural VAR approach, University of Illinios, Urbana-Champaign, Mimeo.

Sims, C. (1980), Macroeconomics and reality, Econometrica, 70: 1-48. 


\section{Tables and Figures}

Table 1 Evolution of industry GVA as percentage of GDP (six largest industries)

\begin{tabular}{ccccccc}
\hline Year & $\begin{array}{c}\text { Finance and } \\
\text { insurance }\end{array}$ & Manufacturing & Construction & Mining & $\begin{array}{c}\text { Professional, } \\
\text { scientific etc. }\end{array}$ & $\begin{array}{c}\text { Health care, } \\
\text { etc. }\end{array}$ \\
\hline 1974 & $5.9 \%$ & $16.2 \%$ & $6.6 \%$ & $5.7 \%$ & $3.1 \%$ & $4.2 \%$ \\
1990 & $8.1 \%$ & $12.7 \%$ & $5.9 \%$ & $7.0 \%$ & $3.8 \%$ & $5.1 \%$ \\
2009 & $9.9 \%$ & $8.4 \%$ & $7.0 \%$ & $6.7 \%$ & $5.9 \%$ & $5.7 \%$ \\
\hline
\end{tabular}

Source: ABS cat; 5206.0 Australian National Accounts: National Income, Expenditure and Product,

Table 37, Indexes of Industrial Production.

Table 2 Impulse response to an official cash rate shock (100 basis points)

\begin{tabular}{|c|c|c|c|c|}
\hline \multirow[t]{2}{*}{ Industries } & \multirow{2}{*}{\begin{tabular}{l}
\multicolumn{1}{l}{ IRF } \\
$\operatorname{Max}(+) /$ or \\
$\operatorname{Min}(-)$
\end{tabular}} & \multicolumn{3}{|c|}{ Cumulative IRF after 2 years } \\
\hline & & $\begin{array}{l}\text { Period of } \\
\text { (Quarter) }\end{array}$ & $\begin{array}{c}\text { effectMax }(+) / \text { or } \\
\operatorname{Min}(-)\end{array}$ & $\begin{array}{l}\text { Period of effect } \\
\text { (Quarter) }\end{array}$ \\
\hline \multicolumn{5}{|c|}{ Industries negatively affected by an unanticipated increase in interest rate } \\
\hline Nonmetallic mineral prod. & $-0.0660 *$ & 3 & -0.0473 & 4 \\
\hline Machinery and equipment & $-0.0437 *$ & 4 & $-0.0701 *$ & 4 \\
\hline Petroleum, coal, chemical, etc. & $-0.0284 *$ & 3 & $-0.0536 *$ & 4 \\
\hline Food, beverage, etc. & $-0.0438 *$ & 2 & $-0.0432 *$ & 2 \\
\hline Metal products & $-0.0661 *$ & 3 & -0.0363 & 8 \\
\hline Textile, clothing and others & $-0.0339 \grave{A}$ & 5 & $-0.0560 *$ & 6 \\
\hline Administrative and support serv. & $-0.0130 *$ & 2 & $-0.038 * *$ & 3 \\
\hline Public administration and safety & $-0.0072 *$ & 2 & $-0.0334 *$ & 2 \\
\hline Construction & $-0.0257^{*}$ & 3 & $-0.0490 *$ & 5 \\
\hline Total Manufacturing & $-0.0223^{*}$ & 3 & $-0.0402 *$ & 4 \\
\hline Accommodation and food services & $-0.0180 *$ & 2 & $-0.0190 *$ & 2 \\
\hline Professional, scientific, etc. & $-0.0158 *$ & 2 & -0.0162 & 2 \\
\hline Wholesale trade & $-0.0168 \dot{A}$ & 3 & $-0.0375^{*}$ & 5 \\
\hline Electricity, gas, water, etc. & $-0.0136^{*}$ & 3 & -0.0080 & 6 \\
\hline Health care and social assistance & $-0.0140 *$ & 2 & $-0.0215^{*}$ & 3 \\
\hline Wood and paper products & $-0.0170 *$ & 3 & $-0.0024 \grave{A}$ & 4 \\
\hline Printing and recorded media & $-0.0214 \dot{A}$ & 4 & -0.0186 & 5 \\
\hline \multicolumn{5}{|c|}{ Industries positively affected by an unanticipated increase in interest rate } \\
\hline Exploration and mining support & $0.0084^{*}$ & 3 & $0.0153^{*}$ & 3 \\
\hline Mining (excluding services) & $0.0590 *$ & 3 & 0.0335 & 3 \\
\hline Rental, hiring, etc. & $0.0205^{* *}$ & 2 & $0.0664 \dot{A}$ & 6 \\
\hline Finance and insurance services & $0.0120 *$ & 4 & $0.0120 *$ & 5 \\
\hline \multicolumn{5}{|c|}{ Industries not affected by an unanticipated increase in interest rate } \\
\hline Total mining & 0.015 & 3 & 0.0088 & 6 \\
\hline Arts and recreation services & -0.0090 & 4 & 0.0113 & 3 \\
\hline Information and telecom. & -0.0091 & 4 & -0.0168 & 4 \\
\hline Retail trade & -0.0057 & 2 & -0.0068 & 2 \\
\hline Education and training & -0.0006 & 2 & -0.0020 & 3 \\
\hline Transport, postal and warehousing & 0.0050 & 5 & 0.0008 & 5 \\
\hline
\end{tabular}

Notes: The functional form of each variable is as specified in Equation 1.

*,ÀIndicates coefficient is significantly different from zero at the $10 \%$ and $20 \%$ level respectively. 
Figure 1 Industry GVA as a percentage of GDP (2009)

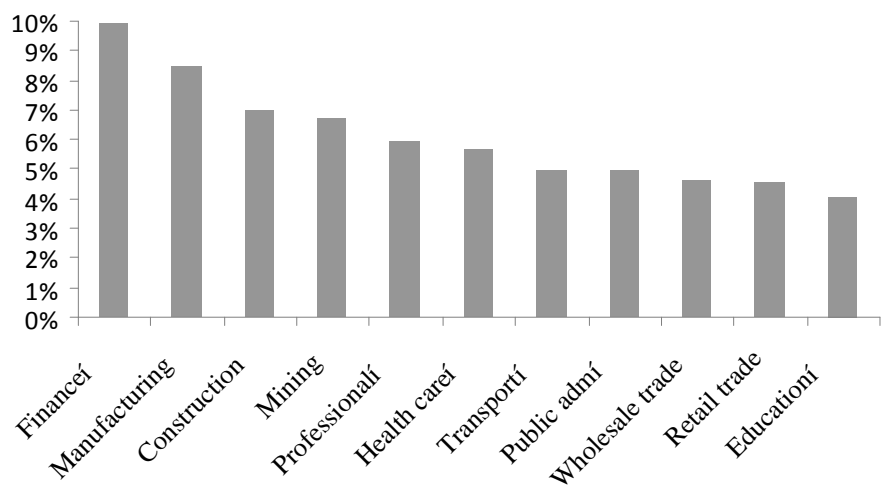

Source: ABS cat; 5206.0 Australian National Accounts: National Income, Expenditure and Product, Table 37, Indexes of Industrial Production.

Figure 2 GVA by firm size (2007)

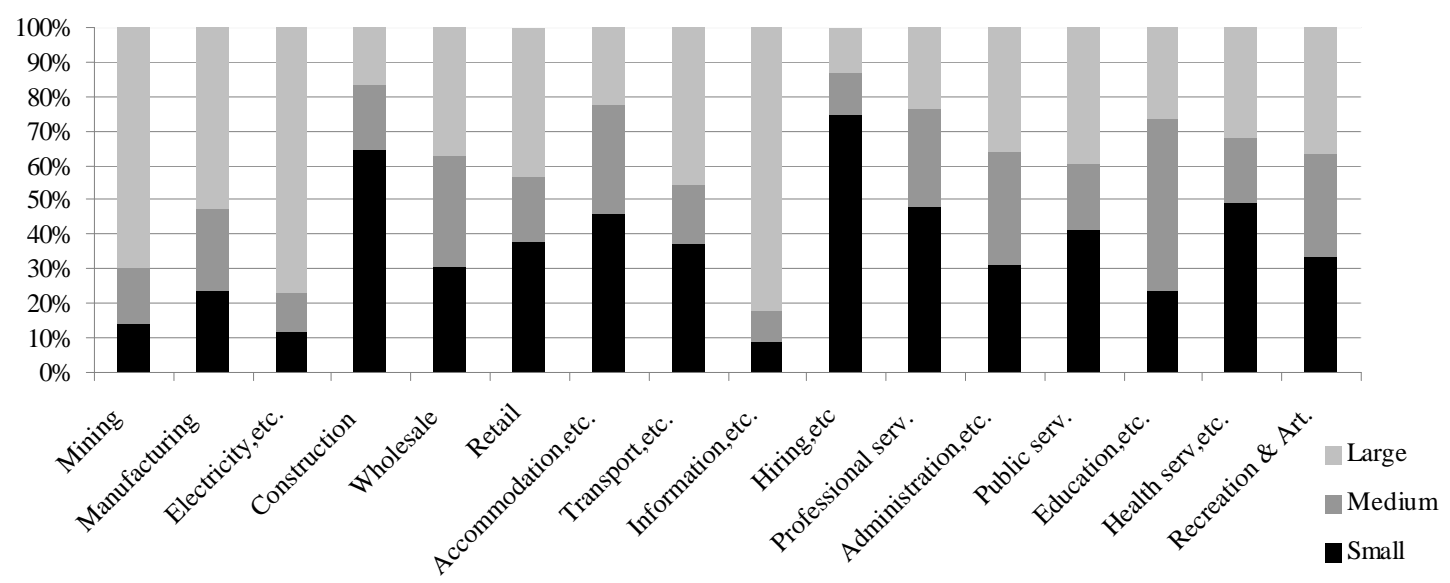

Source: ABS cat: 8155.0 Australian Industry, 2006-2007, Table 4, Business Size, by Division.

Figure 3 Australian international trade in goods and services (2008)

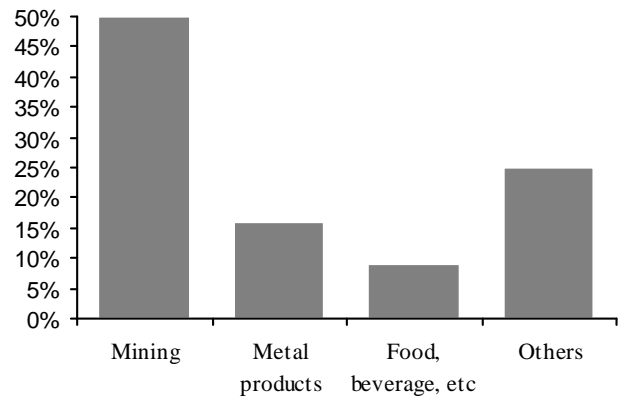

a) Exports by Industry

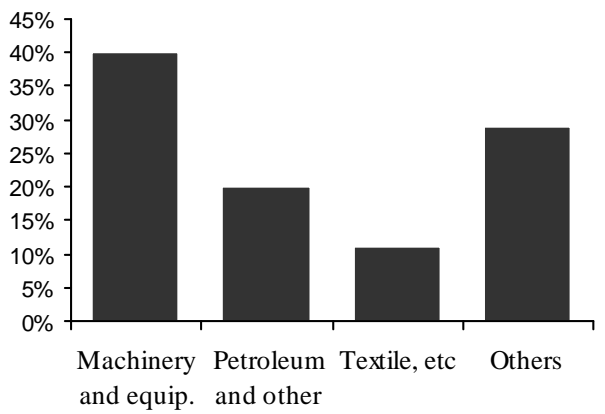

b) Imports by Industry

Source: ABS cat: 5368.0 International Trade in Goods and Services, Australia. Table 22b and 25b . Merchandise Exports/Imports, Industry (ANZCIC 1993). 
Figure 4 Outstanding debt by industries as a \% of GVA (2008)

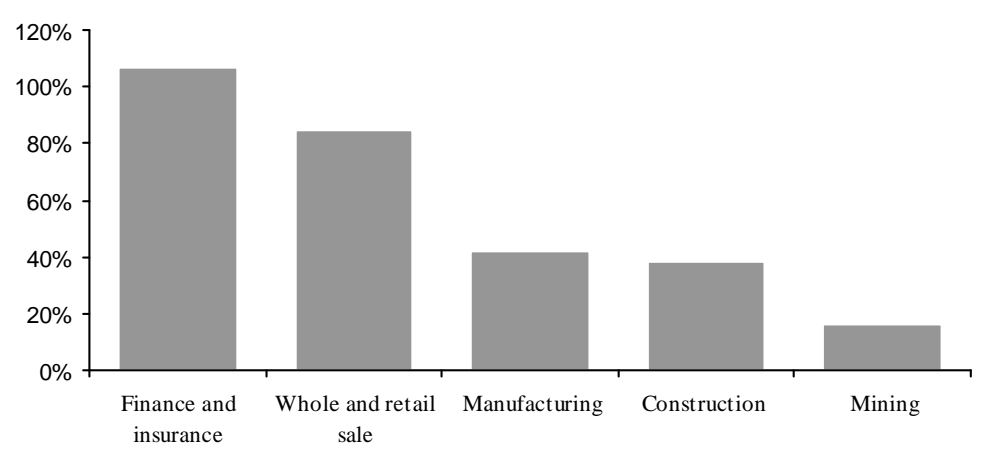

Source: RBA, Bank Lending to Business, Current Prices, Table d08 and ABS, Australian System of National Accounts, Cat: 5204, Table 11, Industry Gross Value Added, Current Prices.

Figure 5 Impulse response to a positive official cash rate shock (100 bps).

(a) Industries
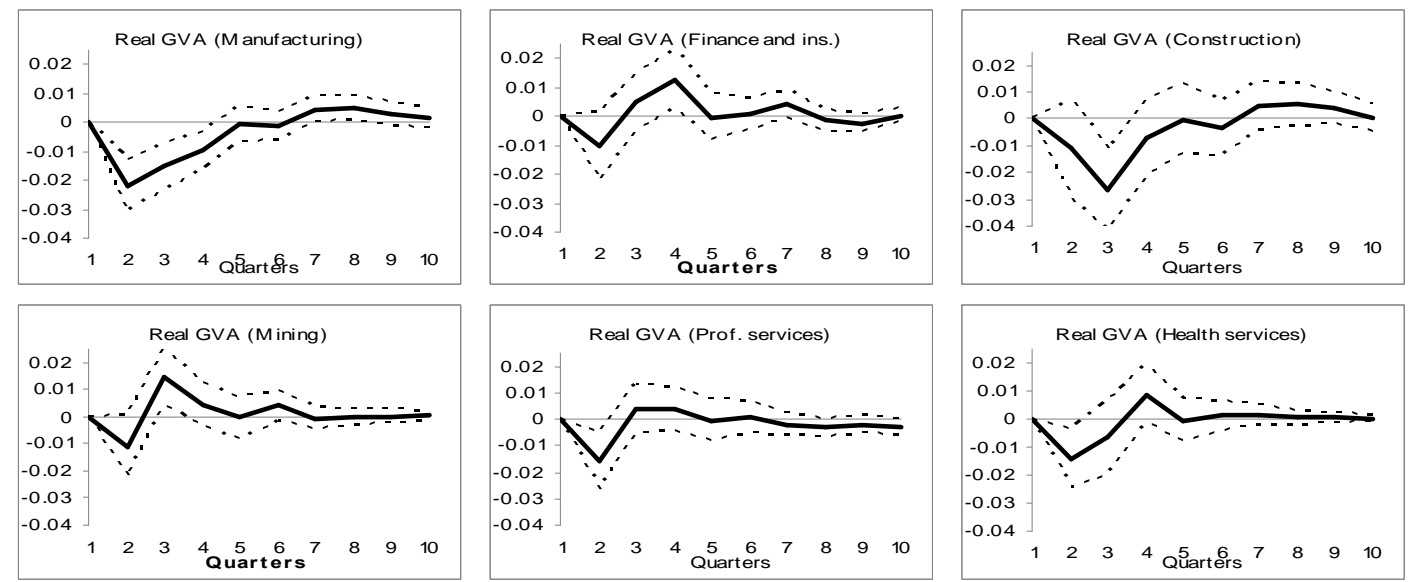

(b) Other macroeconomic variables
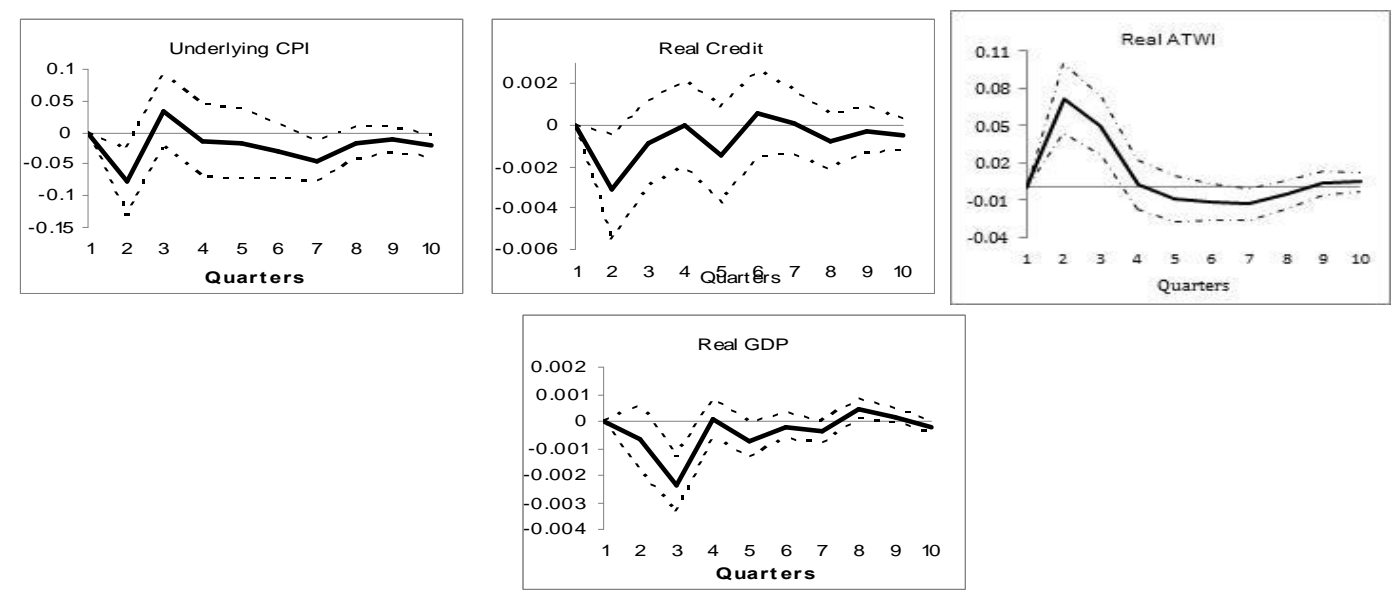
Figure 6 Cumulative impulse response to an official cash rate shock (100 bps), largest industries
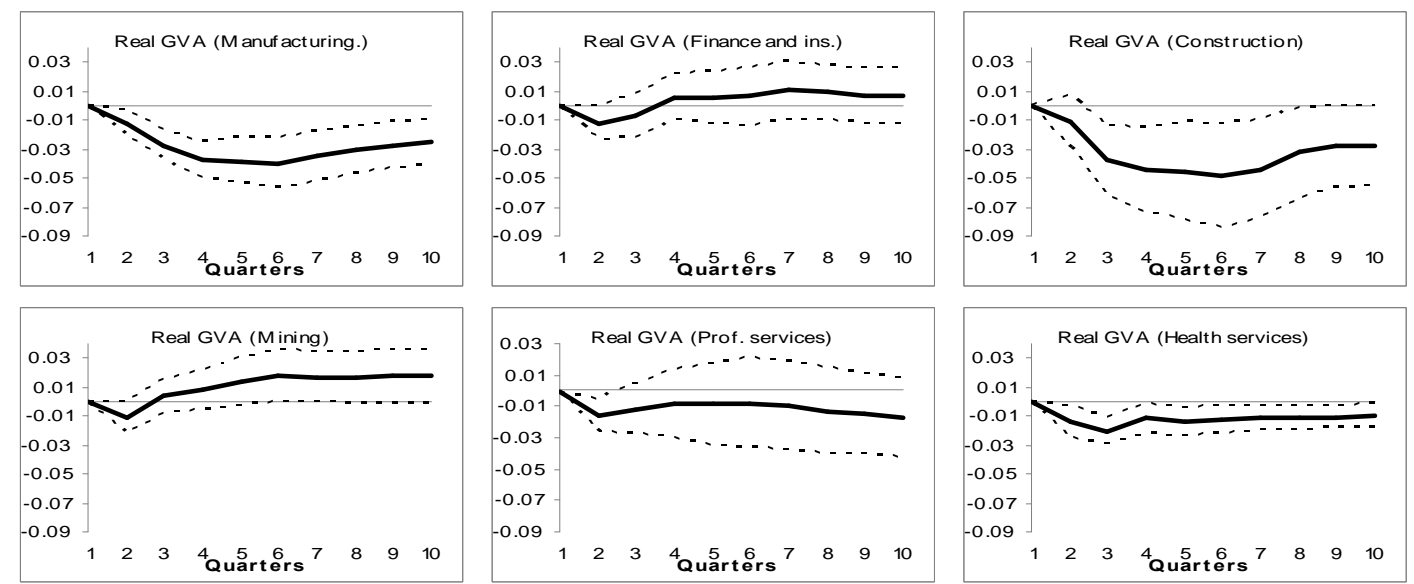

Notes: All industries but mining are statistically significant at $10 \%$ level at the maximum /minimum point. The functional form of each variable is as specified in Equation 1. 


\section{School of Economics and Finance Discussion Papers}

2012-12 The Industrial Impact of Monetary Shocks during the Inflation Targeting Era in Australia, Joaquin L Vespignani

2012-11 Crude Oil Prices and Liquidity, the BRIC and G3 Countries, Ronald A Ratti and Joaquin L Vespignani

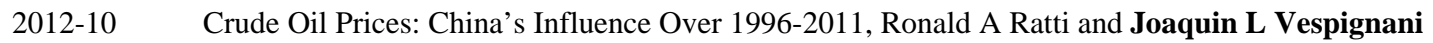

2012-09 Exchange Rate Risk Exposure and the Value of European Firms, Fabio Parlapiano and Vitali Alexeev

2012-08 Ranking Systemically Important Financial Institutions, Mardi Dungey, Matteo Luciani and David Veredas

2012-07 Identification-Robust Inference for Endogeneity Parameters in Linear Structural Models, Firmin Doko Tchatoka and Jean-Marie Dufour

2012-06 Specification Tests with Weak and Invalid Instruments, Firmin Doko Tchatoka

2012-05 Liquidity and Crude Oil Prices: China’s Influence Over 1996-2011, Ronald A. Rattia and Joaquin L. Vespignani

2012-04 On the Validity of Durbin-Wu-Hausman Tests for Assessing Partial Exogeneity Hypotheses with Possibly Weak Instruments, Firmin Doko Tchatoka

2012-03 Endogenous Crisis Dating and Contagion Using Smooth Transition Structural GARCH, Mardi Dungey, George Milunovich, Susan Thorp and Minxian Yang

2012-02 Testing for Partial Exogeneity with Weak Identification, Firmin Doko Tchatoka

2012-01 On the Correspondence Between Data Revision and Trend-Cycle Decomposition, Mardi Dungey, Jan PAM Jacobs and Jian Tian

2011-06 Systematic and Liquidity Risk in Subprime-Mortgage Backed Securities, Mardi Dungey, Gerald P. Dwyer and Thomas Flavin

2011-05 A SVECM Model of the UK Economy and The Term Premium, Mardi Dungey and M. Tugrul Vehbi

2011-04 Do Contact Matter in the Process of Getting a Job in Cameroon? Firmin Doko Tchatoka and Urbain Thierry Yogo

2011-03 Subset Hypotheses Testing and Instrument Exclusion in the Linear IV Regression, Firmin Doko Tchatoka

2011-02 First home Buyers' Support Schemes in Australia - Results Spreadsheet, Mardi Dungey, Graeme Wells and Sam Thompson

2011-01 First home Buyers’ Support Schemes in Australia, Mardi Dungey, Graeme Wells and Sam Thompson

Copies of the above mentioned papers and a list of previous years' papers are available from our home site at http://www.utas.edu.au/economics-finance/research/ 